\title{
Sperm-associated seminal plasma proteins - a novel approach for the evaluation of sperm fertilizing ability of stallions?
}

\author{
Alexandra Reineke, O. Heß, Alexandra Schambony, Anna M. Petrounkina, H. Bader, H. Sieme* \\ and Edda Töpfer-Petersen
}

Institut für Reproduktionsmedizin, Tierärztliche Hochschule Hannover; *Niedersächsisches Landgestüt Celle

\begin{abstract}
Summary
Mammalian cysteine-rich secretory proteins (CRISP) are characterized by 16 cysteine residues forming 8 disulfide bonds. In the horse male genital tract CRISP proteins have been identified in the testis (CRISP-2), in the epididymis (CRISP-1) and in the ampulla (CRISP-3). Using a monospecific avian antibody that recognizes all equine members of the equine CRISP family, CRISP proteins have been immunolocalized at the postacrosomal region of the sperm head and the tail midpiece being associated to the sperm surface during epididymal transit. CRISP's appear to be tightly bound to the sperm surface surviving the passage through the female genital tract, in vitro capacitation and acrosome reaction and extensive washing at high salt concentrations. The number of CRISP molecules tightly bound to the sperm surface could be determined by means of a competitive inhibition ELISA assay and have been shown to correlate ( $p \leq 0.069$, Pearson correlation)/ to correlate significantly ( $p<0.01$, Spearman rank correlation analysis) with the fertility of stallions. Protein concentration of more than 18000 molecules/ sperm cell correlates with good pregnancy and foaling rates. Together with conventional sperm parameters, e.g. progressive motility and sperm concentration, the biochemical marker (CRISP molecules/ sperm cell) allows a better prediction $\left(R^{2}=0.54, p<0.02\right)$ of the stallion fertility rate in vivo and is alternative to other functional tests such as the expensive and time-consuming hemizona assay.
\end{abstract}

Keywords: $\quad$ Epididymal maturation, sperm-egg fusion, sperm membrane, Cysteine-rich secretory proteins (CRISP), stallion fertility, biochemical sperm parameter, ELISA assay

\begin{abstract}
Spermien-assoziierte seminale Proteine im Hengstsamen - Neue praxisrelevante Beurteilungskriterien für die Fertilität des Hengstes?

Cystein-reiche sekretorische Proteine (CRISP) gehören einer wachsenden Familie von Säugerproteinen an. Sie sind durch 16 Cysteinreste charakterisiert, die alle durch Disulfidbrücken gebunden sind. Im Genitaltrakt des Hengstes konnten sie im Hoden (CRISP-2), Nebenhoden (CRISP-1) und in der Samenleiterampulle (CRISP-3) nachgewiesen werden. Mittels eines monospezifischen aviären Antikörpers konnten alle equinen Mitglieder der CRISP-Familie detektiert werden. Sie assoziieren im Verlauf der Nebenhodenpassage an Postakrosom und Mittelstück des Schwanzes. CRISP's binden sehr fest an die Spermatozoenoberfläche und werden bei der Uteruspassage, bei in-vitro-Kapazitation und Akrosomreaktion und bei Behandlung der Spermien in 0,5 M Natriumchlorid-haltigen Medien nicht von der Oberfläche entfernt. Die Anzahl der gebundenen CRISP- Proteinmoleküle, die mittels eines kompetitiven Inhibitionstests auf der Basis eines ELISA's bestimmt werden konnte, korrelierte ( $p \leq 0,069$; Pearson Korrelationsanalyse)/ korrelierte signifikant $(p<0,01$, Spearman Korrelationsanalyse) mit der Fertilität von Hengsten. Eine Proteinkonzentration von mehr als 18000 CRISP-Molekülen/Spermatozoon korreliert mit guter Befruchtungsfähigkeit des Hengstes. Unter Einbeziehung konventioneller Spermienparameter wie Vorwärtsbeweglichkeit und Spermiendichte kann die Voraussage der Fertilität signifikant $\left(R^{2}=0,54 ; p<0,02\right)$ verbessert werden. Dieser neue biochemische Spermienparameter ist damit eine Alternative zu den aufwendigen funktionellen Tests wie beispielsweise dem Hemizona-Assay.
\end{abstract}

Schlüsselwörter: Fertilität, biochemischer Spermienparameter, Spermienreifung, Spermien-Eizellfusion, Spermienmembran, Cystein-reiche sekretorische Proteine (CRISP), ELISA

\section{Introduction}

Mammalian fertilization involves a sequence of specific interactions between the male gamete and the somatic cells of the male and female genital tract culminating in the well-orchestrated cascade of events between the sperm and egg, leading to the union of both gametes (reviewed by Yanagimachi; 1994). After deposition in the female genital tract and reaching the Fallopian tube spermatozoa undergo specific activation processes, e.g. capacitation and hyperactivation that are controlled by the oviductal epithelium enabling sperm to swim to the site of fertilization and to interact with the egg in the appropriate manner. After binding to the zona pellucida (the glycoprotein matrix enveloping the egg) capacitated sperm undergo the acrosome reaction by which proteolytic enzymes are released assisting the acrosome-reacted sperm to penetrate the zona pellucida. The fusion between the acrosome-reacted sperm and the oolemma is a key event in fertilization triggering a series of events known as egg activation that is prerequisite to initiate normal embryonic development. 
In eutherian mammals the ability of sperm to execute the complex sequence of events leading to fertilization develops during epididymal transit. Spermatozoa released by the testis are not able to fertilize an ovum. The interaction of the sperm with the secretion products of the epididymis is an essential feature of sperm maturation. During passage of the epididymis the sperm surface undergoes complex reorganisation processes including the acquisition of new proteins associating to or integrating into the membrane bilayer (reviewed by Brooks, 1987; Kirchhoff, 1999). One of those newly acquired proteins is the so-called DE-protein that has been implicated in the fusion between sperm and egg in the rat. DE-protein is androgen-dependent secreted by the proximal segments of the rat epididymis and associates to the proximal region of the sperm head. Concomitantly with the occurrence of the acrosome reaction DE migrates to the equatorial region being in the right place to participate in the fusion event (Rochwerger and Cuaniscu, 1992; Rochwerger et al., 1992; Cohen et al., 1996). It has been shown that immunization of male rats with the protein leads to infertility by blocking the fusion with the oolemma (Ellermann et al., 1998). DE-protein belongs to the emerging superfamily of secretory proteins, collectively called CRISP (cysteine-rich secretory protein). CRISP's have been identified in humans, rodents, horse, pig and bull (Eberspächer et al., 1995; Hayashi et al., 1996; Schambony et al., 1998a,b; Schambony et al., 1999b). Mammalian CRISP's are characterized by 16 conserved cysteine residues forming 8 disulfide bonds thus stabilizing the threedimensional structure (Magdaleno et al., 1997; Schambony et al., 1998b). Members of mammalian CRISP's are denoted according to their specific tissue expression: testicular CRISP-2, epididymal CRISP-1 and CRISP-3 that is synthesized by the accessory and salivary glands (Eberspächer et al., 1995).

In the horse all three members of the CRISP family have been identified in the male genital tract and have been structurally characterized by cDNA-sequencing (Schambony et al., 1998a,b; Schambony et al. 1999a).

CRISP-3 is synthesized in the equine ampulla that is the main source of seminal proteins. It can be isolated from seminal plasma in considerable amounts allowing structural and functional studies (Calvete et al., 1994). Regarding the putative role of CRISP's in fertilization and the availability of equine CRISP's, a biochemical assay has been developed to determine tightly bound CRISP protein. Here we describe a competitive inhibition ELISA assay to establish a new biochemical sperm parameter that correlates with the fertility of stallions.

\section{Material and methods}

\section{Animals and semen}

Ejaculates have been collected during the breeding season from 25 Thorough blood and warmblood stallions in an age of 3 to 25 years and analyzed for sperm concentration, mo- tility and morphology using standard spermatological methods and criteria.

\section{Immunolocalization of CRISP proteins on spermatozoa}

Sperm have been isolated from testis and epididymis that have been obtained after castration and/or from the slaughterhous. Sperm were collected by slicing the tissues and flushing with PBS $(20 \mathrm{mM}$ sodium phosphate, $135 \mathrm{mM}$ $\mathrm{NaCl}, \mathrm{pH}$ 7.4).

Two hours after insemination (using standard procedures), the uterus of the inseminated mare has been obtained after slaughtering and the sperm were immediately collected by flushing the uterus with PBS.

Sperm were concentrated by centrifugation (200xg, $10 \mathrm{~min}$ ) and subjected to immunofluorescence microscopy as described (Magdaleno et al., 1997). Briefly, sperm suspension $\left(10^{5} \mathrm{sperm} / \mathrm{ml}\right)$ in PBS were smeared on glas slides, airdried and fixed for $15 \mathrm{~min}$ in methanol. The smears were incubated overnight at $4^{\circ} \mathrm{C}$ with $5 \%$ BSA (bovine serum albumin) in PBS to avoid unspecific binding and then sequentially incubated $\left(60 \mathrm{~min}\right.$ at $\left.37^{\circ} \mathrm{C}\right)$ with anti-HSP-3 (1:3000 $(\mathrm{V} / \mathrm{V})$ in $0.5 \% \mathrm{BSA}-\mathrm{PBS})$, biotinylated anti-chicken $\operatorname{lgG}$ in goat. (1:500 (v/v) in 0.5\% BSA-PBS; Dianova) and streptavidin-FITC $(5 \mu \mathrm{g} / \mathrm{ml}$ in $0.5 \%$ BSA-PBS, Calbiochem). Each incubation step are followed by exhaustive washing procedures in $0.5 \%$ BSA-PBS. The smears were covered with Gycerol-PBS (9:1 $\mathrm{V} / \mathrm{v})$ and observed by epifluorescence (Zeiss microscope, 100×10 magnification). Controls were run by omission and by replacement of the first antibody with preimmune serum.

\section{Isolation of CRISP-3}

CRISP-3 was isolated from equine seminal plasma as described by Schambony and coworkers (1998b). Briefly, sperm free seminal plasma was obtained by centrifugation at $12000 \times \mathrm{xg}, 10 \mathrm{~min}$ and subjected to affinity chromatography on heparin-Sepharose CL-6b in TBS (Pharmacia, Sweden). The non-heparin binding fraction was further separated by conventional gelfiltration on Sephadex G50 in TBS (Pharmacia, Sweden). The fraction containing CRISP-3 as judged by SDS-PAGE was purified by hydrophobic interaction chromatography $(\mathrm{HIC})$ on butyl-Sepharose 4FF (Pharmacia, Sweden) using a gradient of ammonium sulfate $\left(1-\mathrm{O} \mathrm{M}\left(\mathrm{NH}_{4}\right)_{2} \mathrm{SO}_{4}\right)$ in $20 \mathrm{mM}$ Tris- $\mathrm{HCl}, \mathrm{pH} 7$. The purified protein eluted as a single peak at $170 \mathrm{mM}$ ammonium sulfate and was dialysed against water and lyophilized.

\section{SDS-Polyacrylamid electrophoresis and Western blotting}

Spermatozoa $\left(50 \times 10^{6} \mathrm{sperm} / \mathrm{ml}\right)$ were extracted by incubation at $37^{\circ} \mathrm{C}$ in sample buffer $(12.5 \mathrm{ml} 1 \mathrm{M}$ glycin, $4 \mathrm{ml} 1 \mathrm{M}$ Tris- $\mathrm{HCl}, 0.5 \%$ SDS, $2.5 \mathrm{mg}$ bromphenol blue, $7.2 \mathrm{ml}$ dis- 
tilled water, $\mathrm{pH}$ 6.8) and after centrifugation applied to SDS-PAGE (20 $\mu \mathrm{l} /$ well) using 15\% separation and 4,5\% stacking gels. Gels were visualized by Coomassie blue or electroblotted on PVDF membranes and probed with a polyclonal antibody directed against CRISP-3 (anti-HSP3 in chicken) using standard protocols as described (Schambony et al., 1998b).

\section{Qantification of CRISP proteins}

CRISP proteins were quantified in sperm free seminal plasma and on ejaculated and washed spermatozoa by means of a competitive inhibition ELISA as described (Dostalova et al., 1994). Spermatotozoa were centrifuged (100xg, $10 \mathrm{~min}$ ) to remove seminal plasma and washed three times in PBS, followed by two washing steps in $0.5 \mathrm{M} \mathrm{NaCl}$ in PBS. The pellet was resuspended and diluted to a final sperm concentration of $2.5 \times 10^{8}$ to $4.9 \times 10^{5} \mathrm{sperm} / \mathrm{ml}$ in PBS/BSA $(0.5 \%)$ containing anti-HSP-3 at a dilution of $1: 150000(\mathrm{v} / \mathrm{v})$ and incubated for $60 \mathrm{~min}$ at $37^{\circ} \mathrm{C}$. After centrifugation of the sperm suspensions (13000xg, $5 \mathrm{~min}$ ) the free antibody concentration in the resulting supernatants were determined by titration against the purified CRISP-3 protein. To this end CRISP-3 $(1 \mu \mathrm{g} /$ well in $100 \mu \mathrm{l})$ were coated onto the ELISA plates (Immobilon, Dynatec) and following blocking with $5 \% \mathrm{BSA}$ in washing buffer $(10 \mathrm{mM}$ Tris- $\mathrm{HCl}$; $\mathrm{pH} 7.4$, $0.12 \mathrm{M} \mathrm{NaCl}, 0.1 \%$ Triton) to avoid unspecific binding, the antibody containing supernatants $(100 \mu \mathrm{l} /$ well; $n=2$ for each sperm concentration) were allowed to incubate for $60 \mathrm{~min}$ at $37^{\circ} \mathrm{C}$. After three washing steps antibody binding was detected by addition of $100 \mu \mathrm{l} /$ well anti-chicken-biotin in goat (Dianova) at a dilution of 1:2000 (v/v), $60 \mathrm{~min}$, at $37^{\circ} \mathrm{C}$, followed by three washing steps and incubation with $100 \mu \mathrm{l} /$ well streptavidin-peroxidase (Dianova; 1:4000 ( $/ \mathrm{v})$, $60 \mathrm{~min}, 37^{\circ} \mathrm{C}$ ). After additional washing steps in washing buffer $(2 x)$ and water $(1 x)$ the plate was developed by addition of $100 \mu \mathrm{l}$ of o-phenyldiamine $(2 \mathrm{mg} / \mathrm{ml}$ in $20 \mathrm{mM}$ citric acid, $50 \mathrm{mM} \mathrm{Na} \mathrm{HPO}_{4} \mathrm{pH} 5.0$ containing $70 \mu \mathrm{l} 30 \%$ $\mathrm{H}_{2} \mathrm{O}_{2} / 100 \mathrm{ml}$ ) for $15 \mathrm{~min}$ at room temperature. The enzyme reaction was stopped with $4 \mathrm{M} \mathrm{H}_{2} \mathrm{SO}_{4}(50 \mu \mathrm{l})$ and OD at $492 \mathrm{~nm}$ was determined using an automated micro ELISA reader $(\mathrm{ICN})$. Alternatively seminal plasma with decreasing protein concentrations were incubated with the antibody solution and further processed as described above.

For each ELISA plate a standard inhibition curve was determined by incubating the purified CRISP-3 protein at concentrations of $12,5 \mu \mathrm{g} / 100 \mu \mathrm{l}$ to $12,5 \mathrm{pg} / 100 \mu \mathrm{l}$ with the anti-HSP-3 antibody $\left(1: 150000(\mathrm{v} / \mathrm{v})\right.$, for $60 \mathrm{~min}$ at $\left.37^{\circ} \mathrm{C}\right)$. After sedimentation of the antigen-antibody complex by centrifugation at $16000 \times \mathrm{xg}, 30 \mathrm{~min}$, the remaining free antibody was detected as described above.

The CRISP protein concentrations were determined on the basis of the standard inhibition curve as $\mathrm{mg} / \mathrm{ml}$ (seminal plasma) or $\mathrm{pg} / 10^{9} \mathrm{sperm}$ cells (sperm suspension). The number of molecules/sperm cell were calculated under consideration of the molecular weight of CRISP $\left(M_{r} 25000\right)$ and the Avogrado's number $\left(\mathrm{N}=6.023 \times 10^{23}\right)$.

\section{Data analysis}

Two up to four ejaculates have been studied for each stallion. The concentration of CRISP-3 protein in seminal plasma $(\mathrm{mg} / \mathrm{ml}$ ) and CRISP proteins on spermatozoa (molecules/sperm cell) and have been determined for individual stallions. The later has been considered as a biochemical sperm parameter. In order to establish the specificity of this individual parameter the parameter-free analysis was performed (Müller, 1991). The normality and non-normality of the data were checked prior to the analysis. The conventional spermatological parameters and the biochemical parameter were related with the fertility of the stallions based on their pregnancy rates (23 out of 25 stallions). For the quantification of these relationships the Spearman and Pearson correlation coefficients were calculated. Chi-Quadrat Test was used to perform the frequency analysis for the stallions with respect to the protein concentration and pregnancy rates. In order to optimize the correlation between different parameters the multiple regression analysis was used (Gogolok et al., 1992; Schuemer et al., 1992). The effects with significance level $p \leq 0.05$ for the null hypothesis was considered as significant and with level $p \leq 0.1$ as noticeable. The analysis was performed using statistic procedures MEANS, UNIVARIATE, CORR, NPARIWAY, FREQ and STEPWISE of the Statistic Package SAS (SAS Institute Inc:, Version 1985, SAS/STAT user's Guide 1989)

\section{Results}

Distribution of CRISP proteins on spermatozoa during epididymal transit and in the female genital tract

Sperm isolated from the testis does not show any immunofluorence staining indicating that the concentration of CRISP proteins on sperm is low or negligible. Entering the caput epididymis sperm show minor staining of the postacrosomal region and the midpiece (not shown) that becomes more intensive when the sperm passes the corpus epididymis and remains constant in the cauda epididymis and at ejaculation (fig.1a-c). Ejaculated sperm show occassionally an additional staining of the acrosomal region.

Sperm that have been collected from the uterus two hours after insemination (fig.1d) exhibit a similar distribution pattern than epididiymal and ejaculated sperm demonstrating that CRISP proteins associating with the sperm surface during epididymal transit survive the first barriere in the female genital tract.

\section{Establisment of the competitive inihibition ELISA assay}

CRISP-3 is one of the major proteins of equine seminal plasma. It has been isolated from sperm free seminal plasma in considerable amounts by a three-step procedure including heparin affinity chromatography, gelfiltration and HIC-chromatography yielding a highly purified material as 
judged by SDS-PAGE, HPLC and mass spectrometry (for methods see Schambony et al., 1998b). The homogenous protein fraction was used for standardisation and calibration of the competitive inhibition ELISA assay.
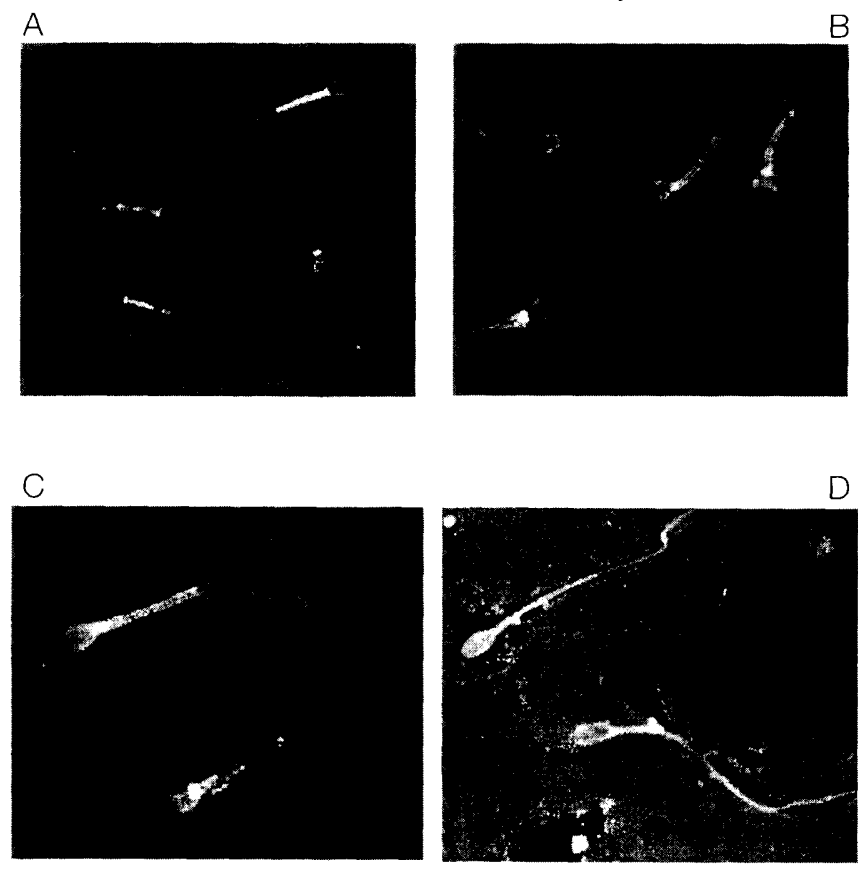

Fig.1. Immunolocalization of CRISP proteins on equine spermatozoa of different maturation steps by means of an avian anti-HSP-3 antibody directed against seminal CRISP-3. A slight staining (not shown) is first detected in the midpiece region of the sperm tail when the sperm pass the caput epididymis. A.) In the corpus region of the epididymis the post-acrosomal and the midpiece region are stained. B.) Spermatozoa isolated from the cauda epididymis and C.) ejaculated spermatozoa show a similar distribution pattern. D.) Spermatozoa isolated from the uterus 2 hours after insemination show still staining at the post-acrosomal and midpiece region.

Immunlocalization von CRISP in equinen Spermatozoen unterschiedlicher Reifungsstadien mittels eines aviären anti-HSP-3 Antikörpers (gerichtet gegen equines CRISP3). Eine leichte Markierung ist am Mittelstück des Schwanzes zu beobachten (nicht dargestellt), wenn das Spermatozoon den Nebenhodenkopf passiert. A.) Im Nebenhodenkörper markiert das Mittelstück und die post-akrosomale Region srärker an, um dann B.) im Nebenhodenschwanz und C.) bei ejakulierten Spermatozoen ein nahezu gleichbleibendes Fluoreszenzmuster zu zeigen. D.) Spermatozoen, die zwei Stunden nach Insemination aus dem Uterus der Stute gewonnen wurden, wiesen immer noch eine Markierung an Postakrosom und Mittelstück auf.

The antibody (anti-HSP-3) raised against the seminal plasma protein have been shown to recognize all types of equine CRISP proteins e.g. CRISP-1, CRISP-2 and CRISP-3 with a high and comparable specificity as shown by Westernblotting following SDS-PAGE and the ELISA assay (data not shown). Unspecific binding and cross-reactivity with other seminal plasma or sperm components was negligible. The antibody has been therefore found to be suitable for the evaluation of total CRISP protein concentration in equine semen.
CRISP proteins have been identified on spermatozoa that are roughly unwrapped from seminal plasma by gentle centrifugation. By means of Westernblotting following SDSPAGE of the sperm extracts a broad band exhibiting an apparent molecular mass of about $25 \mathrm{kDa}$ has been detected with the monospecific anti HSP-3 antibody. Washing steps in PBS lead to considerable reduction of the band intensity (fig.2). By the competitive ELISA assay it was shown that

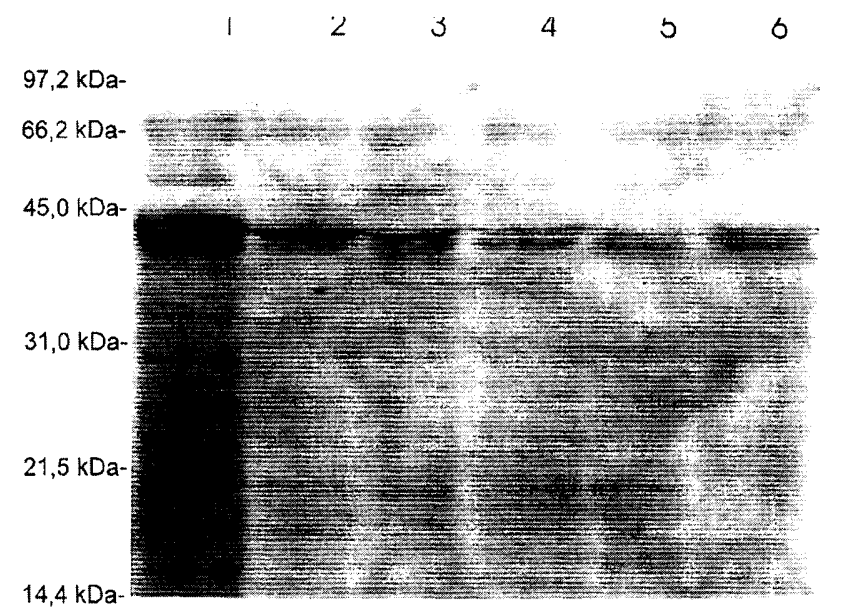

Fig.2. Westernblots after SDS-PAGE of sperm extracts obtained after the washing procedures when probed with the avian anti-HSP-3 antibody directed against equine CRISP-3. 1. Sperm extracted after centrifugation. 2. Sperm after first PBS washing step. 3. Sperm after the second and 4 . the third PBS washing step. 5. Sperm after the first and 6 . the second salt-washing step in PBS/0.5 M NaCl. A double band with the apparent molecular weight of about $25 \mathrm{kDa}$ can be detected thereby the intensity of the single bands changes concomitantly with the release of ampullary CRISP-3.

Nachweis von CRISP Proteinen am Westernblots nach SDS-PAGE von Spermienextrakten. 1. Ejakulierte Spermatozoen nach Zentrtifugation. 2. Spermatozoen nach dem ersten (2), nach der zweiten (3) und dritten (4) Waschung mit PBS. 5. Spermatozoen nach der ersten (5) und dem zweiten (6) Hochsalzwaschschritt in PBS/ $\mathrm{NaCl}$. Eine Doppelbande $\left(M_{r} 25000\right)$ kann detektiert werden. Die Intensität der einzelnen Banden verändern sich im Verlauf der Waschschritte durch den Verlust von ampullären CRISP-3.

three washing steps in PBS reduces the amount of CRISP protein coating the sperm of about $80-90 \%$. Additional washing steps in salt-containing buffers lead to a further small reduction. However, the protein concentration remains constant after treatment of the sperm by three PBS and two salt-washing steps indicating that a portion of CRISP proteins remains tightly bound to the sperm cell. The change in CRISP protein concentration between the forth, fifth and sixth salt-washing step has been found statistically not significant (fig.3). Examination of the washed sperm preparations by Westernblotting reveals the existence of two bands with a molecular mass difference of about $1 \mathrm{kDa}$. During the washing procedure the intensity of the smaller protein band decreases whereas the band exhibiting the higher molecular mass appears to remain con- 
stant (fig.2). Comparison with the isolated seminal plasma protein (CRISP-3) and the epididymal CRISP proteins (not shown) indicates that the decrease of the low molecular mass band is due to the release of the seminal CRISP-3 $\left(M_{r} 24987\right)$ that is loosly attached to the sperm cell. The epididymal CRISP protein having the slightly higher molecular mass (CRISP-1, $M_{r}$ 25640) largely survives the washing procedure. The washing steps under hyperosmotic conditions lead to loss of the acrosomes as could be demonstrated by routine morphological staining procedure. Testicular intraacrosomally localized CRISP proteins are therefore completely lost. The total CRISP protein concentration that remains tightly bound to the sperm cell is composed of the seminal and the epididymal CRISP proteins that associates to the sperm cell during epididymal transit and at ejaculation.

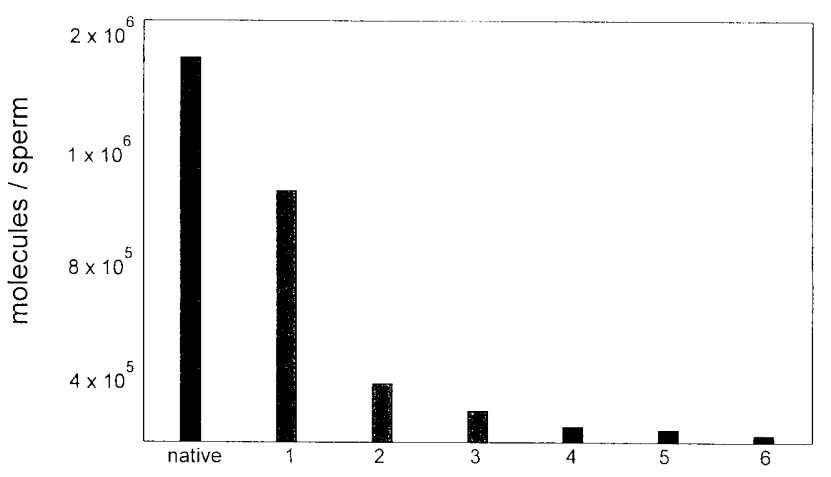

Fig.3. Quantification of the sperm-bound CRISP's during washing procedure as determined by the competitive inhibition ELISA assay using the avian anti-HSP-3 antibody. Native: CRISP protein concentration at ejaculated spermand, at sperm after the first (1), second (2) and third (3) PBS washing step; after the first (4), second (5) and third (6) salt-washing step in PBS/0.5 M NaCl. The differences of sperm-bound CRISP protein between the swecond and third salt-washing step is not statiscally significant.

Quantifizierung der spermiengebundenen CRISP Proteine im Verlauf der Waschprozedur mittels des kompetitiven Inhibitionsassays. Native: CRISP-Konzentration an ejakulierten Spermatozoen nach Zentrifugation. Spermiengebundene CRISP-Konzentration nach erster (1), zweiter (2) und dritter (3) PBS-Waschung sowie nach erster (4), zweiter (5) und dritter (6) Hochsalzwaschung in PBS/ $\mathrm{NaCl}$. Die Differenz der Anzahl der spermiengebundenen CRISP Moleküle/Spermatozoon zwischen zweiter und dritter Hoschsalzwaschung ist statistisch nicht signifikant.

Quantification of the total CRISP protein concentration in equine semen.

The descriptive statistics of the biochemical and conventional parameters are shown in table 1. The data are representative of at least two to four ejaculates of each of 25 stallions.

\section{Seminal plama}

Seminal plasma contains about $2.5 \mathrm{mg} / \mathrm{ml}$ CRISP proteins representing about $5-7 \%$ of its total protein content. The concentration of seminal CRISP in different ejaculates of an individual stallion shows high variations (standard deviation = 4.4 as calculated for 25 stallions). The correlations with the fertility and pregnancy data of the individual stallion have been found to be not statistically significant or noticeable.

\section{Spermatozoa}

The total concentrations of CRISP proteins on the sperm cell after extensive washing steps removing acrosomal and loosly attached proteins have been found in the pmole range (about 30 pmole/ $10^{9}$ sperm cells). To emphasize differences in the sperm population of different animals, protein concentration is expressed as molecules/sperm cell and is in average 18900 molecules/sperm cell. The examination of different ejaculates of the same animal documents that the number of molecules bound to sperm can be understood as a stallion specific parameter (the specificity follows from the non-parametric analysis at the significance level $p \leq 0.05$ ).

Comparison with the pregnancy rates of the tested 23 stallions used in an Al program allows to conclude that a narrow relationship exists between sperm-bound CRISP protein and fertility. The number of CRISP molecules correlated positively with the fertility data (pregnancy rate) of the stallions (Pearson correlation coefficient $R=0.39, p \leq 0.069$, Spearman rank correlation coefficient $R=0,39, p<0.01$ ) (fig. 4).

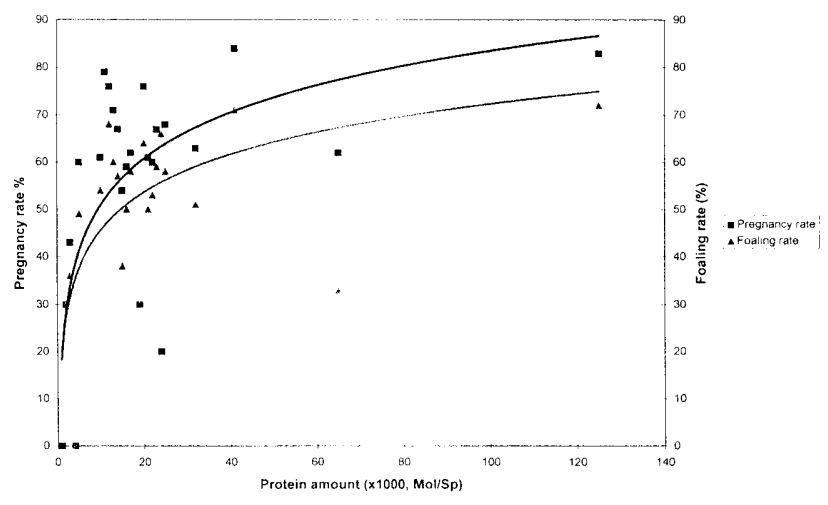

Fig.4: Relationship between protein concentration, pregnancy rate and foaling rate. The number of sperm-bound CRISP protein correlates significantly $(p<0.05)$ with the pregnancy rate, and statistically noticeable $(p<0.1)$ with the foaling rate.

Zusammenhang zwischen CRISP-Konzentration, Trächtigkeitsrate und Abfohlrate. Die Anzahl der CRISP Moleküle/ Spermatozoon korreliert significant mit der Trächtigkeitsrate $(p<0.05)$ und auffallend mit der Abfohlrate $(p<0.1)$

The stallions exhibiting high values of sperm-bound CRISP concentrations (about more than 18900 molecules/sperm cell) also show higher fertility rates whereas low protein concentration appears to be mostly accompagnied by reduced fertility. Using the Chi-Square test a significant difference between the frequency of appearance of over-average and under-average fertility rates can be shown with respect to the number of sperm-bound CRISP molecules. All stallions (26.1\%) with over-average concentrations (> 18000 molecules/sperm cell) showed high fertility rates (60\%). Among stallions with under-average concentrations of sperm-bound CRISP (17 stallions) the frequency of donors showing higher 
and lower fertility was comparable: $47.1 \%$ and $52.9 \%$ (or $34.8 \%$ and $39.1 \%$ of total stallion number), respectively. Further detailed examination of the group with under-average fertility in order to estimate subfertility was statistically not ensued due to the fact that only 3 stallions showed fertility rates $<45 \%$. The average amount of CRISP- protein was 5900 molecules / sperm, the fertility rate $34.3 \%$.

Tab. 1. Statistics of biochemical and conventional sperm parameters

Statistik der biochemischen und konventionellen Spermienparameter

\begin{tabular}{|c|c|c|c|c|}
\hline parameter & $\begin{array}{c}\mathrm{N} \\
\text { (stallions) }\end{array}$ & Mean & Std. Dev. & Std.Mean \\
\hline $\begin{array}{l}\text { protein amount } \\
\text { (molecules/sperm) }\end{array}$ & 25 & 18942 & 24462 & 4892.5 \\
\hline $\begin{array}{l}\text { protein concentration in } \\
\text { seminal plasma }(\mu \mathrm{g} / \mu \mathrm{l})\end{array}$ & 25 & 2.5 & 4.4 & 0.9 \\
\hline pregnancy rate (\%) & 23 & 60.5 & 19.4 & 4.0 \\
\hline foaling rate $(\%)$ & 23 & 51.6 & 17.6 & 3.7 \\
\hline volume of semen $(\mathrm{ml})$ & 23 & 46.2 & 16.6 & 3.5 \\
\hline $\begin{array}{l}\text { sperm concentration } \\
(\mathrm{mio} / \mathrm{ml})\end{array}$ & 23 & 228.7 & 89.6 & 18.7 \\
\hline progressive motility (\%) & 23 & 52.1 & 10.6 & 2.2 \\
\hline local motility (\%) & 23 & 16.9 & 5.4 & 1.1 \\
\hline abnormal sperms (\%) & 21 & 42.2 & 13.2 & 2.9 \\
\hline
\end{tabular}

Out of the conventional sperm parameters progressive motility and sperm concentration showed positive Pearson correlations with the fertility rate of the stallions: $R=0.38$, $p \leq 0.08$ (progressive motility) and $R=0.48 p<0.02$ (sperm concentration).

Neither progressive motility nor sperm concentration have been found to be sufficient powerful sperm parameters to predict the fertility potential of stallions. The definiteness (R-Square) of these models is at relatively low level: the percentage of the deviation explained by these models is less than $30 \%$ as shown by the partial regression models for the significant acting predictor sperm concentration $\left(R^{2}=0.29\right)$, progressive motility $\left(R^{2}=0.13\right)$ and sperm-bound CRISP concentration $\left(R^{2}=0.12\right)$. The consequent optimizing of the multiple regression models leads to the increase of the definiteness values of the models with more than one kind of predictor. The two-predictor model (ELISA-quantified CRISP protein concentration and motility) shows $R^{2}=0.43$, whereas the optimized three-predictor model (progressive motility, sperm concentration and CRISP protein concentration) showed $R^{2}=0.54(p<0.02)$.

\section{Discussion}

In the equine male genital tract CRISP proteins are first expressed in the testis as has been shown at mRNA level by RT-PCR and at protein level by Western blotting of tissues and sperm extracts. Entering and passing the epididymal duct maturing sperm associate CRISP's (particularly CRISP-1) synthesized by the epididymal epithelium (Schambony et al., $1998 a, b)$. The protein appears to bind tightly to the membrane lipid bilayer. The ability of secretory proteins to interact specifically with phospholipid vesicles has been demonstrated for the major bovine seminal plasma protein, PDC-109 (Müller et al., 1998). Preliminary studies with equine CRISP-3 points to its hydrophobic lipid-binding ability (Töpfer-Petersen, Müller and Schambony, unpublished). During epididymal transit CRISP's may therefore occupy binding sites of the sperm membrane particularly at the equatorial and postacrosomal region as well at the tail midpiece. At ejaculation a small portion of ampullary CRISP-3 may bind directly to the membrane or may be exchanged with epididymal CRISP-1 while the vaste of CRISP-3 loosly coats the sperm surface. Under capacitating conditions and during acrosome reaction most of the protein coat is lost with exception of the tightly bound proteins at the post-acrosomal and midpiece region of the sperm (Schambony et al., 1998b). The CRISP proteins are localized at the right position of the acrosome-reacted sperm to interact with the oocyte vitelline membrane after the sperm has penetrated the zona pellucida. Although the potential role of CRISP in the fusion events between sperm and oocyte has been only shown in the rat (Rochwerger et al., 1992; Cohen et al., 1996; Ellermann et al., 1998) the occurrence of these proteins in all tested mammalian species may point to a general fusion mechanism involving CRISP proteins. The significance of CRISP proteins in sperm-oocyte interaction in horses needs further investigations. However, several lines of evidence suggest their functional relevance in equine reproduction.

A quantitative assay measuring the amount CRISP proteins in semen has been therefore developed on the basis of a competitive inhibition assay (Dostalova et al., 1994). The stallion is unique among domestic animals by the synthetic activity of its ampulla expressing a member of the cysteinerich secretory protein family, CRISP-3 in considerable amounts. In contrast, in other tissues e.g. salivary gland or in the male genital tract of other species, e.g. pig, cattle and rodents CRISP's are synthesized in minor concentrations. Equine CRISP-3 is therefore a mammalian member of this wide-spread family that can be easily obtained in amounts allowing structural and functional studies. The protein shows no self-aggregation and no tendency to form complexes with other seminal plasma components and can be isolated from seminal plasma as a single protein (Magdaleno et al., 1997). This features together with the high antigeneity of CRISP-3 had allowed to develop a highly monospecific antibody that works in high dilutions thus minimizing unspecific binding. The anti-HSP-3 antibody (HSP-3 stands for horse seminal plasma protein 3 (CRISP-3) as eluted from analytical HPLC) recognizes all members of equine CRISP's, e.g. testicular CRISP-1, epididymal CRISP-2 and salivary and ampullary CRISP-3 with comparable affinity. It has also been used to detect CRISP's in other species such as pig and cattle (Schambony et al.,1999a,b). The good cross-reactivity restricted to members of mammalian CRISP's may be due to their sequence homology of more than $50 \%$ and the highly conserved three-dimensional structure stabilized by eight di- 
sulfide bridges that is characteristic for the CRISP family (Magdaleno et al., 1997, Schambony et al., 1998b).

High specificity of an antibody directed against a functional relevant sperm potein is prerequisite for the establishment of a valuable biochemical sperm parameter for the diagnosis of male sub- or infertility that could be easily performed using the ELISA technique. It may be superior to functional tests such as the hemizona-binding assay ( $H Z A$; Oehninger et al., 1997) because of the availability of material, better standardization and routine handling. As it has been shown in human andrological diagnostic, even a single functional assay has a low predictory validity. The combination with other (conventional) spermatological parameters increases the accuracy of fertility prediction. Similarly, the predictivity of CRISP-protein concentration expressed as bound molecules/spem cell alone is comparable to that of progressive motility and sperm concentration, however, the combination significantly increases the predictory validity.

At present stage of research it is open, whether the reduction of bound CRISP proteins is accompgnied in vivo with a reduced ability of equine sperm to fuse with the oocyte thus leading to sub- or infertility. Alternatively, the reduced binding of CRISP proteins to the sperm surface during epididymal transit may be a marker of a general incomplete maturation of the sperm. Preliminary studies on infertile and cryptoichid stallions point to a disturbed gene transcription in those animals which may not be restricted to the CRISP proteins (Reinecke and Töpfer-Petersen, unpublished; Kirchhoff, 1999).

In conclusion, it has been developed an ELISA assay to determine an additional biochemical sperm parameter that allows in combination with other sperm parameters, e.g. progressive motility and sperm concentration, the prediction of the fertility of stallions or of a defined sperm population thus aiding the management in equine A.I.

\section{Literature}

Brooks D.E. (1987) Androgen-regulated epididymal secretory proteins associated with the post-testicular sperm development. Ann. NY Acad. Sci. 513, 179-194

Calvete J.J., Nessau Sabine., Mann K., Sieme H., Klug E., Töpfer-Petersen Edda. (1994) Isolation and biochemical characterization of stallion seminal plasma proteins. Reprod. Dom. Anim. 29, 411-426

Cohen Deborah.J., Munice Maria.J., Cuasnicu Patricia.S. (1996) Mammalian sperm-fusion: The development of rat oolemma fusibility during oogenesis involves the appearance of binding sites for sperm protein DE. Biol Reprod. 55, 200-206

Dostalova Zuzanna., Calvete J.J., Sanz Libia., Töpfer-Petersen Edda (1994) Quantification of boar spermadhesins in accessory sex gland fluids and on the surface of epididymal, ejaculated and capacitated spermatozoa. BBA 1200, 48-54

Eberspächer U., Roosterman D., Krätschmar J., Haendler B., Habenicht Ursula-Fredericke, Becker A., Quensel Christina, Petri T., Schleuning W.-D., Donner P. (1995) Mouse androgen-dependent epididymal glycoprotein CRISP-1 (DE/AEG): isolation, biochemical characterization, and expression in recombinant form. Mol. Reprod. Dev. 42, 157-172

Ellerman D.A., Brantua Veronica S., Perez Martinez Sivina, Cohen Deborah.J., Conesa Daniela, Cuasnicu Patricia S. (1998) Potential contraceptive use of epididymal proteins: immunization of male rats with epididymal protein DE inhibits sperm fusion ability. Biol. Reprod. 59, 1029-1036

Gogolok J., Schuemer R., Ströhlien G. (1992) Datenverarbeitung und statistische Auswertung von SAS. Band 1: Einführung in das Programsystem, Datenmanagement und Auswertung. Gustav Fischer Verlag, Stuttgart, Jena, New York

Hayashi M. Fujimoto S., Takano H., Ushiki T., Abe K., Ishikura H., Yoshida M.C., Kirchhoff Christiane, Ishibashi T., Kasahara M. (1996) Characterization of a human glycoprotein with a potential role in sperm-egg fusion: cDNA cloning, immunohistochemical localization, and chromosomal assignement of the gene (AEGL-1). Genomics 32, 367-374

Kirchhoff C. (1999) Gene expression in the epididymis. Int. Rev. Cytol. $188,133-202$

Magdaleno Leticia., Gasset Maria, Verea J., Schambony Alexandra M., Urbanke K., Raida M., Töpfer-Petersen Edda, Calvete J.J. (1997) Biochemical and conformational characterisation of HSP-3, a stallion seminal plasma protein of the cysteine-rich secretory protein (CRISP) family. FEBS Lett. 420, 179-185

Müller H. (1991) Wahrscheinlichkeitsrechnung und Mathematische Statistik-Lexikon der Stochastik. Akademie Verlag, Berlin

Müller P., Erlemann K.-R., Müller Karin, Calvete J.J., Töpfer-Petersen Edda., Marienfeld Kathleen, Herrmann A. (1998) Biophysical characterization of the interaction of bovine seminal plasma protein PDC-109 with phospholoipid vesicles. Eur. Biophys. J. 27, 33-41

Oehninger S., Mahony M., Ozgur K., Kruger T., Franken D. (1997) Clinical significance of human sperm-zona pellucida binding. Fertil. Steril. 67, 121-127

Rochwerger Leonora., Cuasnicu Patricia.S. (1992) Redistribution of rat sperm epididymal glycoprotein after in vitro and in vivo capacitation. Mol. Reprod. Dev. 29, 357-364

Rochwerger Leonora, Cohen Deborah J., Cuasnicu Patricia.S. (1992) Mammalian sperm-egg fusion: the rat egg has been complementary sites for a sperm protein that mediates gamete fusion. Dev. Biol. 153, 83-45

SAS/STAT User's Guide (1989) Version 6, Fourth Edition. SAS Insitute Inc., Cary NC

Schambony Alexandra, Gentzel M., Wolfes H., Töpfer-Petersen Edda (1999a): Molecular cloning of equine CRISP-1 and CRISP-2 proteins. BBA, submitted.

Schambony Alexandra, Gentzel M., Reinecke Alexandra, Hasenleder Petra, Wolfes H., Töpfer-Petersen Edda (1999b) Expression of CRISP-proteins in the boar genital tract. Biol Reprod., submitted

Schambony Alexandra, Hess O., Gentzel M., Töpfer-Petersen Edda (1998a) Expression of CRISP proteins in the male genital tract. J. Reprod. Fertil. Supplement 53, 67-72

Schambony Alexandra., Gentzel M., Wolfes H., Raida M., Neumann U., Töpfer-Petersen Edda (1998b) Equine CRISP-3; primary structure and expression in the male genital tract. BBA 1387, 206-216

Shuemer R., Ströhlien G., Gogolok J. (1992) Datenverarbeitung und statistische Auswertung mit SAS. Band 2: Komplexe statistische Analyseverfahren. Gustav Fischer Verlag, Stuttgart, Jena, New York Yanagimachi R. (1994) Mammalian fertilization. In: The Physiology of Reproduction, second edition (eds Knobil E., Neill J.D.) Raven Press, New York pp189-317

\section{Acknowledgement}

The authors wish to thank the BMBF for supporting the project $(01 \mathrm{KY}$ 9503/3; ETP) and Mrs. Christiane Hettel for excellent technical assistence.

\section{Prof. Edda Töpfer-Petersen}

Institut für Reproduktionsmedizin

Tierärztliche Hochschule Hannover

Bünteweg 15,

D-30559 Hannover

Tel: 0049-511/9538519

Fax: 0049-511/9538504

Email.Etp@repro.tiho-hannover.de 